ESRI

SURVEY AND

STATISTICAL

REPORT SERIES

NUMBER 95

JULY 2020

\section{MANAGING MASS UNEMPLOYMENT FLOWS DURING THE COVID-19 PANDEMIC}

\section{SEAMUS MCGUINNESS AND ELISH KELLY}

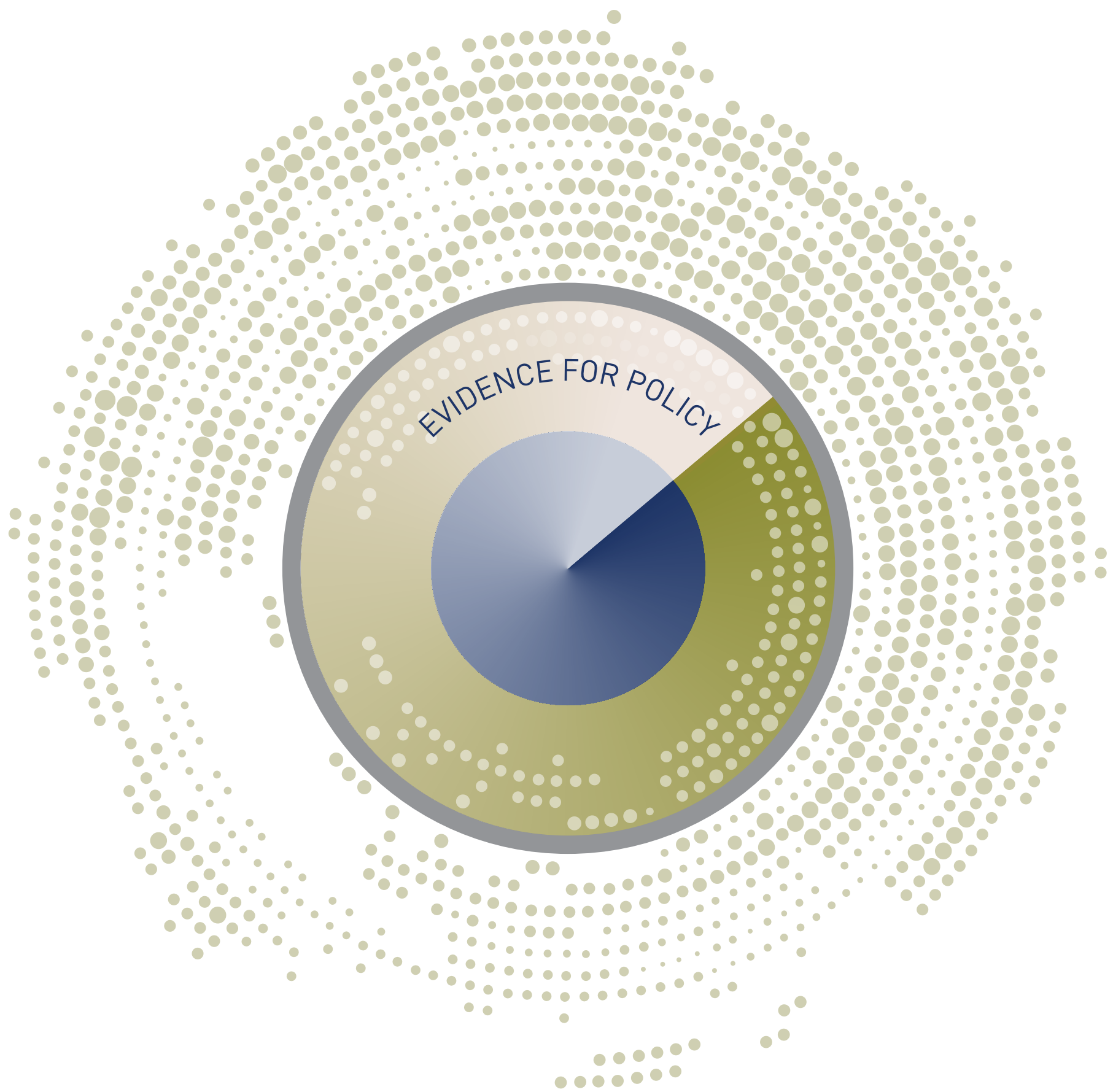




\title{
MANAGING MASS UNEMPLOYMENT FLOWS DURING THE COVID-19 PANDEMIC
}

\author{
Seamus McGuinness
}

Elish Kelly

July 2020

\section{SURVEY AND STATISTICAL REPORT SERIES}

\section{NUMBER 95}

Available to download from www.esri.ie

DOI: https://doi.org/10.26504/sustat95

ISBN 978-0-7070-0533-1

(C) 2020 The Economic and Social Research Institute Whitaker Square, Sir John Rogerson's Quay, Dublin 2

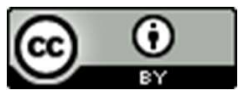

This Open Access work is licensed under a Creative Commons Attribution 4.0 International License (https://creativecommons.org/licenses/by/4.0/), which permits unrestricted use, distribution, and reproduction in any medium, provided the original work is properly credited. 


\section{ABOUT THE ESRI}

The mission of the Economic and Social Research Institute is to advance evidencebased policymaking that supports economic sustainability and social progress in Ireland. ESRI researchers apply the highest standards of academic excellence to challenges facing policymakers, focusing on 12 areas of critical importance to 21st Century Ireland.

The Institute was founded in 1960 by a group of senior civil servants led by Dr T.K. Whitaker, who identified the need for independent and in-depth research analysis to provide a robust evidence base for policymaking in Ireland. Since then, the Institute has remained committed to independent research and its work is free of any expressed ideology or political position. The Institute publishes all research reaching the appropriate academic standard, irrespective of its findings or who funds the research.

The quality of its research output is guaranteed by a rigorous peer review process. ESRI researchers are experts in their fields and are committed to producing work that meets the highest academic standards and practices.

The work of the Institute is disseminated widely in books, journal articles and reports. ESRI publications are available to download, free of charge, from its website. Additionally, ESRI staff communicate research findings at regular conferences and seminars.

The ESRI is a company limited by guarantee, answerable to its members and governed by a Council, comprising 14 members who represent a cross-section of ESRI members from academia, civil services, state agencies, businesses and civil society. The Institute receives an annual grant-in-aid from the Department of Public Expenditure and Reform to support the scientific and public interest elements of the Institute's activities; the grant accounted for an average of 30 per cent of the Institute's income over the lifetime of the last Research Strategy. The remaining funding comes from research programmes supported by government departments and agencies, public bodies and competitive research programmes.

Further information is available at www.esri.ie 


\section{THE AUTHORS}

Seamus McGuinness is a Research Professor at the Economic and Social Research Institute (ESRI), an Adjunct Professor at Trinity College Dublin and a Research Fellow at the Institute of Labor Economics (IZA) in the University of Bonn.

Elish Kelly is a Senior Research Officer at the ESRI, holds an adjunct research position at Trinity College Dublin (TCD), and is a Research Fellow at the Institute of Labor Economics (IZA) in the University of Bonn. 


\section{CONTENTS}

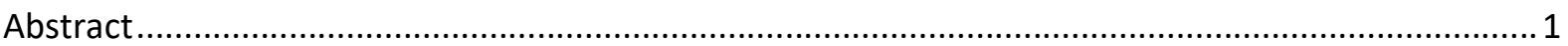

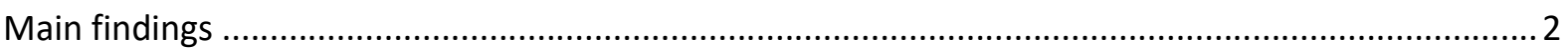

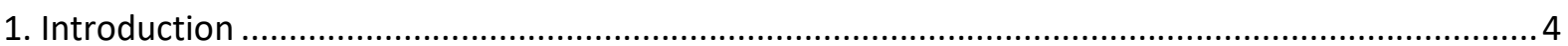

2. The proposed transition from emergency restrictions ........................................................ 6

3. The implications of the influx of Pandemic Unemployment Payment claimants to the Live Register for Public Employment Services ...................................................................................... 10

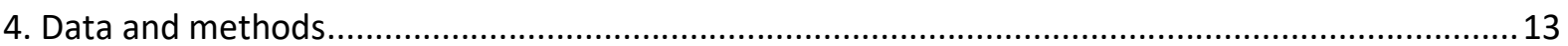

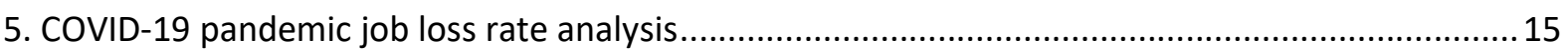

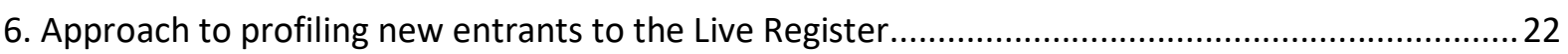

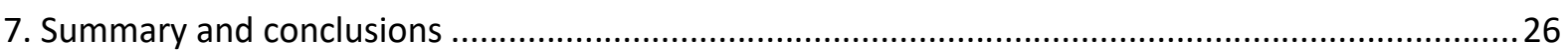

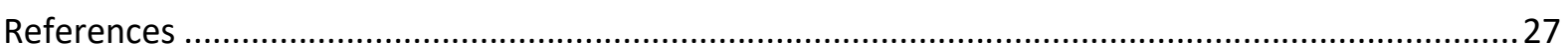

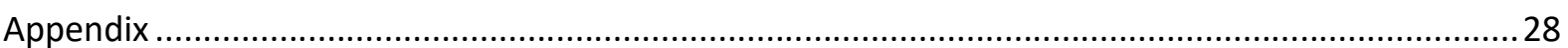

\section{LIST OF TABLES}

Table 1 Opening of economic sectors in Ireland under Government's revised roadmap: Phases 1-4

Table 2 COVID-19 job loss rates: economic sector ............................................................ 17

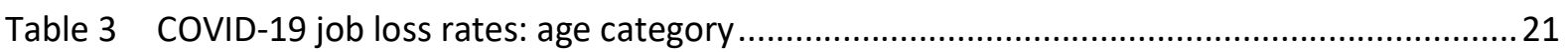

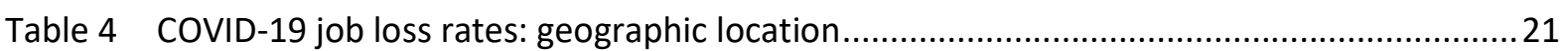

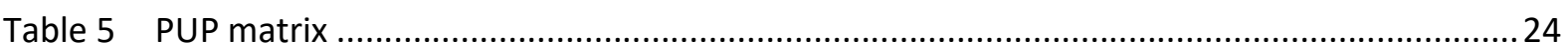

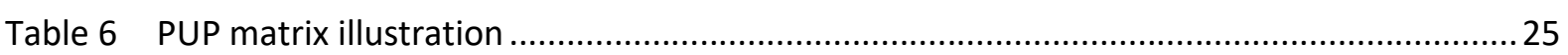

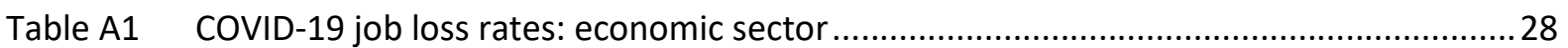

\section{LIST OF FIGURES}

Figure 1 Claimant exits from the Live Register during 2007 
CSO

DEASP

EWSS

JA

$\mathrm{JB}$

LFS

PES

PEX

PUP

SPU

TWSS
Central Statistics Office

Department of Employment Affairs and Social Protection

Employment Wage Subsidy Scheme

Jobseeker's Allowance

Jobseeker's Benefit

Labour Force Survey

Public Employment Services

Probability of Exit

Pandemic Unemployment Payment

Stability Programme Update

Temporary Wage Subsidy Scheme 
As an immediate consequence of the COVID-19 health pandemic, Ireland's standard seasonally adjusted unemployment rate went from $4.8 \%$ in February 2020 to an estimated peak of $28.2 \%$ in April when those in receipt of the Pandemic Unemployment Payment (PUP) are included. Since then, the Central Statistics Office's COVID-19 adjusted measure of unemployment has fallen gradually from $28.2 \%$ to stand at $22.5 \%$ in June 2020 . Due to COVID-19, Ireland's Public Employment Services (PES) are likely facing substantial constraints arising from the rapid increase in jobseeker claimants qualifying for, and/or seeking, their employment supports. Furthermore, when the PUP scheme is closed at the end of March 2021 it is expected that PES will have to transfer a large number of individuals from the emergency PUP to the Live Register. These circumstances create a huge administrative burden that will stretch Ireland's PES. In this study, we use a combination of administrative and Labour Force Survey (LFS) data to both analyse the distribution of COVID-19-related unemployment and propose a process that will help Ireland's PES identify new PUP claimants likely to be at the greatest risk of subsequently falling into long-term unemployment. The approach is designed to help ensure that limited PES resources can be targeted towards highrisk PUP claimants qualifying for, and/or seeking, employment supports. 
- The COVID-19 pandemic has led to an unprecedented crisis in the Irish labour market. The seasonally adjusted unemployment rate in February 2020 stood at $4.8 \%$. When account is taken of individuals currently in receipt of the COVID-19 Pandemic Unemployment Payment (PUP), the estimated unemployment rate increased to a peak of $28.2 \%$ in April before falling gradually to $22.5 \%$ in June 2020.

- The number currently (as of 28 July 2020) in receipt of the PUP is 286,900. Given the continued uncertainty around the behaviour of the virus, and in the absence of a vaccination, the scale of individuals transferring from the PUP to standard unemployment benefits is likely to be large when the payment's extension ends at the beginning of April 2021. Even before this time period, a number of individuals in receipt of the PUP are likely to seek employment supports. Such a large increase in the demand for employment services will, potentially, place existing activation services under an enormous strain.

- The objective of the current study is to develop a short-run categorisation strategy that can be used to broadly categorise claimants accessing Ireland's Public Employment Services (PES) activation services, in terms of their expected risk of future long-term unemployment.

- We classify economic sectors into three risk categories on the basis of reemployment probabilities, which, in turn, are based on the sector's job loss rate. Specifically, we have high-risk, medium-risk and low-risk, with high-risk sectors having a job loss rate of $60 \%$ and above, medium-risk $20-59 \%$ and lowrisk less than $20 \%$.

- The five main economic sectors with high job loss rates are:

(i) other personal service activities, such as hairdressers and beauticians (76.5\%);

(ii) accommodation (75.2\%);

(iii) real estate activities (74.8\%);

(iv) food and beverage service activities (73\%);

(v) specialised construction activities, such as demolition and site preparation, electrical, plumbing and other construction installation activities (68\%).

We also classify two travel industry sectors as high-risk given that this industry is likely to one of the last to resume operations and will likely experience more medium-term impacts.

- High-risk sectors accounted for $13.6 \%$ of total employment prior to the pandemic and make up $37.5 \%$ of PUP claimants. Medium-risk sectors accounted for $28.7 \%$ of employment prior to COVID-19 and $33.3 \%$ of PUP claimants. Lowrisk sectors accounted for $55.4 \%$ of employment prior to the health pandemic and $19.9 \%$ of PUP claimants. 
- The impact of the pandemic is currently significantly skewed with respect to age. Those aged under 25 have the highest job loss rate (46.7\%) but the lowest share of total employment in the economy (11\%). In contrast, those aged 55 and above have the lowest job loss rate (18.6\%) and also a low share of employment (18.4\%).

- With respect to geographic location, the border region has the highest job loss rate $(29.1 \%)$ but a low share of total employment (7.5\%). Dublin has the lowest job loss rate $(23.9 \%)$ and the highest share of employment in the economy (30.5\%).

- We propose that the primary means of sorting individuals according to their risk of becoming long-term unemployed should relate to whether they were previously employed in a high-risk sector. Factors such as age, previous unemployment history and geographic location can also be used to repartition claimants according to risk. We set out a potential approach that will allow the Department of Employment Affairs and Social Protection (DEASP) to categorise claimants' risk of subsequent long-term unemployment on a scale of 1 to 9 .

- The proposed framework is flexible, as the PES can adjust the sectoral employment thresholds, or add additional individual characteristics to the criteria, in order to repartition the flows to meet objectives or resource requirements. 


\section{INTRODUCTION}

The COVID-19 health pandemic has led to an unprecedented crisis in the Irish labour market. The seasonally adjusted unemployment rate in February 2020, calculated using the standard methodology by the Central Statistics Office (CSO), stood at $4.8 \% .{ }^{1}$ However, when account is taken of individuals currently in receipt of the COVID-19 Pandemic Unemployment Payment (PUP), the estimated unemployment rate increased to a peak of $28.2 \%$ in April: as of June 2020 , the CSO's COVID-19-adjusted measure of unemployment stood at $22.5 \% .^{2}$ Based on the CSO's monthly unemployment data, the numbers unemployed rose from 119,400 regular jobseekers in January 2020 to 694,683 by April 2020 when the PUP claimants are incorporated. This PUP claimant figure currently (28 July) stands at 286,900 . In addition, 68,400 employers are at present registered with the Revenue Commissioners for the COVID-19 Temporary Wage Subsidy Scheme (TWSS), with an estimated 400,000 employees currently being supported by the scheme. ${ }^{3}$ The TWSS is designed to allow employers to keep paying their staff during the pandemic and, as such, should enable employees to return quickly to work as the economy begins to open up.

When initially introduced, the PUP and the TWSS were set to run for a period of 12 weeks, until 8 June 2020. On 5 June, the then Minister for Employment Affairs and Social Protection announced that the PUP would be extended until 10 August, with the TWSS continuing until 31 August. In revealing its July Jobs Stimulus Plan on 23 July 2020, ${ }^{4}$ the Taoiseach announced that the PUP would be extended until the 1 April 2021, with the payment progressively cut between now and then to align with the Jobseeker's Benefit (JB) payment rate. ${ }^{5}$ In addition, the Taoiseach announced that the TWSS $^{6}$ is to be replaced by the Employment Wage Subsidy Scheme (EWSS)

https://www.cso.ie/en/releasesandpublications/er/mue/monthlyunemploymentjune2020/ (accessed 21 July 2020 ).

This estimate is derived by combining those on the PUP and those on the Live Register. However, it is not clear exactly what proportion of those currently receiving the PUP would qualify for a standard jobseeker payment (Jobseeker's Allowance or Jobseeker's Benefit).

3 https://www.gov.ie/en/press-release/2ea1e-update-on-payments-awarded-for-covid-19-pandemic-unemploymentpayment-and-enhanced-illness-benefit/ (accessed 28 July 2020).

$4 \quad$ The stimulus plan is a $€ 7.4$ billion package consisting of over 50 measures to help businesses reopen, get people back to work and build economic confidence because of the impact of COVID-19.

$5 \quad$ Initially the PUP was a flat rate of $€ 350$ per week, but since 29 June 2020 the payment amount is linked to a claimant's earnings. This adjustment to the PUP, along with other amendments, was revealed when the first extension of the payment was announced on 5 June 2020. In announcing the jobs stimulus plan, the government revealed that the PUP scheme will close to new claimants from 17 September 2020.

$6 \quad$ TWSS is available to employers from all sectors, except for the public and non-commercial semi-state sectors, that have lost a minimum of $25 \%$ of turnover because of the COVID-19 pandemic. Employers have to make a declaration to Revenue confirming that this has taken place. The TWSS is available to employers that can top-up their employees' wages and those that are not in a position to do this. Until 4 May 2020, the scheme refunded employers up to a maximum of $€ 410$ per week for each qualifying employee. Since 4 May, the scheme is based on employees' average take-home pay (i.e. after the payment of tax, Universal Social Charge (USC) and Pay Related Social Insurance (PRSI)) in January and February 2020. For example, if this take-home pay was below €412 per week, the level of subsidy payment is $85 \%$ of average take-home pay. If the employee's take-home pay was between $€ 412$ and $€ 500$ per week, a flat rate of $€ 350$ per week is paid (for more details on the rates, see: 
from 1 September 2020 until 31 March 2021. ${ }^{7}$

When the PUP is terminated, individuals still in receipt of the payment and TWSS/EWSS claimants whose employers were not able to remain in business will be transferred to the Live Register and will receive a regular jobseeker payment. Even in the event that almost all TWSS/EWSS claimants and a substantial proportion of those in receipt of PUP return to their jobs or find employment as the economy reopens, it is likely that large numbers of individuals from these COVID-19 income support schemes will enter the Live Register as new claimants once the pandemic unemployment supports are ended.

Nevertheless, the scale of the unemployment problem remains uncertain, and there is some degree of variation in available estimates of COVID-19 related unemployment. Under a scenario where restrictions remain in place for 12 weeks, the Economic and Social Research Institute (ESRI) projects that unemployment will rise to $18 \%$ in Quarter 2 (Q2) before falling back to just under $11 \%$ by the end of the year. The Department of Finance, in its Stability Programme Update (SPU) published in April 2020, projects that unemployment will rise to 22\% in Q2 before falling back to average $13.9 \%$ for the year. The SPU analysis also forecasts unemployment to fall to an average of $9.7 \%$ in 2021 . Similarly, the Irish Central Bank sees unemployment increasing to $22.4 \%$ in Q2 2020 before falling back to $15.8 \%$ in Q3 and $10.5 \%$ in Q4. In contrast, analysis from the European Union (EU) sees unemployment rising to $7.7 \%$ in 2020 before falling to $7 \%$ in 2021 . From these projections it is clear that the majority of economic institutions are predicting extreme increases in the unemployment rate in Q2 and Q3 of 2020 relative to what the unemployment rate was in the first quarter of the year $(4.7 \%){ }^{8}$

The objective of the current study is to develop a short-run categorisation strategy that can be used by the DEASP'S PES, in the absence of a more simplified and updated Probability of Exit (PEX) profiling tool, ${ }^{9}$ to broadly categorise claimants accessing activation services, in terms of their expected risk of future long-term unemployment. The reason for developing this short-run categorisation tool is to assist the DEASP'S PES to allocate its scarce resources to PUP claimants most in need of assistance to reintegrate into the labour market, among those that access their activation services.

https://www.citizensinformation.ie/en/employment/unemployment_and_redundancy/covid19_temporary_wage_s ubsidy_scheme.html (accessed 18 May 2020).

7 Employers whose turnover has fallen by $30 \%$ will receive a flat-rate subsidy of up to $€ 203$ per week per employee. This includes seasonal staff and new employees. New firms operating in impacted sectors will also be eligible (see: https://www.gov.ie/en/publication/7e4dd-backing-irelands-businesses-supporting-and-creating-jobs/) (accessed 24 July 2020).

8 https://www.cso.ie/en/releasesandpublications/er/lfs/labourforcesurveylfsquarter12020/(accessed 21 July 2020).

9 See O'Connell et al. (2009). 


\section{THE PROPOSED TRANSITION FROM EMERGENCY RESTRICTIONS}

The timeframe under which emergency unemployment and furlough payments are likely to be withdrawn can be broadly determined by the time period over which economic restrictions will be relaxed. Based on the Government's Roadmap for Reopening Society and Business, ${ }^{10}$ its reconfigured roadmap (announced 5 June) and its Revised Roadmap for Reopening Ireland (launched 19 June), ${ }^{11}$ all parts of the economy are expected to have reopened by the third quarter of 2020. Details of the opening up of the various economics sectors under the Government's revised roadmap are set out in Table 1.

A phased return of outdoor workers, such as those in the construction and agricultural sectors - and businesses that support such sectors - commenced on 18 May 2020, the date that marked the start of Phase 1 of the Government's roadmap. Segments of the motor trade industry, some home repair and maintenance services and health-related providers (e.g. opticians) also resumed operations under Phase 1. Only businesses within Phase 1 sectors that can adhere to social distancing requirements were permitted to reopen. During Phase 2, which commenced on 8 June, all retail outlets, except for shopping centres, that could control the number of individuals staff and customers interacted with reopened: shopping centres reopened on 15 June. ${ }^{12}$ Again, social distancing measures needed to be met during Phase 2, including workers maintaining a 2-metre distance from others. These requirements also have to be met during Phase 3 , which began on 29 June. During this period, cafés, restaurants and pubs providing on-premises food and beverages, with social distancing and strict cleaning measures adhered to, resumed business. Under the initial roadmap, more 'high-risk' sectors that involved direct physical contact between people for periods of time (e.g. hairdressers, barbers, salons) were not due to recommence business until the 20 July, but their reopening date was brought forward to Phase 3 under the revised roadmap. Also, hotels (but not hotel bars) and holiday parks for social and tourist activities were allowed to reopen on a limited occupancy basis with social distancing measures adhered to, and also gyms and swimming pools.

During the final reopening phase, Phase 4, which was set to take effect on 20 July but was postponed on 16 July until at least 10 August, a phased return to work

10 https://www.gov.ie/en/news/58bc8b-taoiseach-announces-roadmap-for-reopening-society-and-business-andu/?referrer=/roadmap/

11 Under the reconfigured roadmap, dates for the opening up of certain economic sectors and public amenities were brought forward, and the number of phases for reopening the economy was reduced from five to four. For example, all retail sectors were permitted to open in Phase 2 ( 8 June) instead of over Phases 2 (small retail outlets) to 5 (shopping centres).

12 In order to be able to reopen, shopping centres needed to implement measures to ensure that people did not congregate at benches, fountains or food courts. 
across all remaining sectors is being permitted. This includes pubs, bars and hotel bars. Across all phases, social distancing, hand hygiene and cleaning requirements need to be met and adhered to, otherwise businesses will not be permitted to resume economic activity.

Phase 1- 18 May 2020

1. Phased return of outdoor workers

2. Remote working for all that can do so

Retailers to reopen:

- Hardware stores

- Builders' merchants and gardening suppliers

- Agriculture; garden centres and farmers' markets

- Opticians, optometrists, hearing test providers and sellers of hearing aids

- Motor vehicle, motorcycle and bicycle retailers and repair facilities

- Office products and services; electrical, IT and phone sales, home repair and maintenance services

- Schools/college buildings to facilitate remote learning for teachers/lecturers

Phase 2- 8 June 2020

1. Workers that can safely maintain 2 -metre distance from others

2. Organisations to develop plans for return to onsite working

3. Remote working for all that can do so

Shops, other commercial businesses and social amenities to reopen:

- Retailers that can control the number of individuals staff and customers interact with

- Shopping centres (15 June)

- Marts

- Public libraries

Phase 3-29 June 2020

1. Workers that can safely maintain 2-metre distance from others

2. Remote working for all that can do so

3. Compliance with work protocols and health guidance monitored by State agencies

Shops, other commercial businesses and social amenities to reopen:

- Crèches, childminders and pre-school facilities

- Hairdressers, barbers, beauty salons, etc.

- Wellbeing services (e.g. massage therapy, acupuncture)

- Cafés/restaurants/pubs providing on-premises food/beverages

- All remaining retail (e.g. bookmakers), services (e.g. driving schools) and commercial activities

- Museums, galleries and other cultural outlets

- Sports team competitions (e.g. GAA, soccer) - limitations on spectators (50 indoor and 200 outdoor)

- Public swimming pools

- Hotels (but not hotel bars), hostels, caravan parks, and holiday parks for social and tourist activities

- Theatres and cinemas

- Indoor recreational venues (e.g. bowling alleys, bingo halls)

- Gyms, dance studios, indoor classes (e.g. yoga) and sports clubs

Phase 4- 10 August 2020

1. Phased return to work across all sectors 
2. Workers that can safely maintain 2-metre distance from others

3. Remote working for all that can do so

4. Education institutions open on a phased basis at beginning of the 2020/2021 academic year

Shops, other commercial businesses and social activities to reopen:

- Pubs, nightclubs, discos, hotel bars and casinos

- Gatherings of up to 100 people indoors and 500 people outdoors

Source: Constructed from Roadmap for Reopening Society and Business and Revised Roadmap for Reopening Ireland (Government of Ireland). ${ }^{13}$

While this is the Government's plan for reopening the country, at any stage the plan can be rolled back if the numbers infected by, or dying from, COVID-19 start to increase: this was the reason for the postponement of Phase 4 until 10 August. Thus, when people can fully return to work, or those in businesses that do not survive the pandemic can find new employment, is still unknown. Nevertheless, as it stands, most parts of the economy should be reopened by the end of August 2020.

In revealing its July Jobs Stimulus Plan on 23 July 2020, the Government announced that it was extending the PUP until the beginning of April 2021. At this point, the Government plans to discontinue this COVID-19 unemployment income support. Once this takes place, the DEASP will commence the process of transferring those still in receipt of the PUP to a regular jobseeker payment - a Jobseeker's Allowance (JA) or Jobseeker's Benefit (JB) payment - and, consequently, have them registered on the Live Register. The standard JA/JB rate for adults aged 25 and over is $€ 203$ per week. This is also the payment rate that those who are transferred from the PUP to the Live Register will receive on 1 April 2021. Between now and then, there will be a gradual reduction in the existing PUP payment level, linked to previous earnings, in order to bring the payment into line with the existing jobseeker payments so that there will be no sudden drop in income support for those in receipt of the PUP when the payment is terminated

Given the continued uncertainty around the behaviour of the virus, and in the absence of a vaccination, the scale of individuals transferring from the PUP to JA or JB is likely to be quite large and will put a considerable strain on PES. Even prior to any administrative transfers from PUP to JA/JB, Ireland's PES are likely to come under strain from large numbers of PUP claimants seeking help in finding new employment. While it is highly likely that many of those in receipt of a PUP will not meet the qualifying criteria for JA/JB when the scheme ends at the end of March 2021 , such claims will still need to be assessed. Even accepting that a proportion of PUP recipients will not subsequently be classified as unemployed, Ireland will,

13 https://www.gov.ie/en/news/58bc8b-taoiseach-announces-roadmap-for-reopening-society-and-business-andu/?referrer=/roadmap/ (accessed 18 May and 3 July 2020). 
undoubtedly, experience an immediate growth in the numbers officially unemployed that will be historically unprecedented. While the unemployment rate increased from a low of $4.6 \%$ in 2005 to $15.5 \%$ in 2012 during the last global recession, the growth in numbers occurred over a seven-year period. 


\section{THE IMPLICATIONS OF THE INFLUX OF PANDEMIC UNEMPLOYMENT PAYMENT CLAIMANTS TO THE LIVE REGISTER FOR PUBLIC EMPLOYMENT SERVICES}

Ireland's Public Employment Services (PES) currently possess a statistical profiling system that is used to categorise new claimants in terms of their estimated risk of remaining unemployed for a period of 12 months or more (i.e. long-term unemployed). The econometric model that underpins the Irish statistical profiling approach is described in O'Connell et. al (2009). The basic concept is that, on registering a new unemployment claim, each jobseeker is asked a series of questions around their personal characteristics (e.g. educational attainment, health) and labour market and unemployment histories (job duration, Community Employment (CE) scheme participation, etc.). These data, along with some administrative data captured on claimants on the Live Register (e.g. gender, age, spousal earnings), are then run through a software program and the claimant's Probability of Exiting (PEX) the Live Register prior to a 12-month unemployment duration is calculated. In particular, a PEX score is produced based on the outputs of an econometric model.

The PEX model is used by Ireland's PES to allocate its limited resources to those most in need of assistance to reintegrate into the labour market. In particular, support is more heavily targeted at claimants with a higher risk of becoming longterm unemployed, which is signified by a low PEX score. In contrast, individuals with a high PEX score are only subject to light support, on the grounds that they have been identified as being more likely to exit to employment relatively quickly with minimal assistance needed from the PES. The current application of the PEX model, within Ireland's labour market activation framework, is described by Kelly et al. (2019). Kelly et al. (2019) indicate that new jobseeker claimants are placed into high, medium and low PEX categories, with the intensity of the support provided by the PES highest (lowest) for low (high) PEX claimants.

The ability of a country to implement a profiling tool, like the PEX model, seems an obvious advantage in the current circumstances of this pandemic, as it would enable an overwhelmed PES system to more effectively target its limited resources on claimants most likely to become subsequently long-term unemployed as a result of COVID-19, and, therefore, the claimants most in need of assistance. Equally, it would help ensure that valuable resources are not expended on jobseekers with favourable labour market characteristics (e.g. high levels of educational attainment) that are likely to leave the Live Register quickly without assistance. 
The rationale that underpins the profiling approach is illustrated by Figure 1, which plots a Kaplan-Meier (KM) curve capturing the typical exit pattern of unemployment claimants from the Live Register by claim duration. The graph relates to data on claimants from 2007. In particular, the KM curve is generated using data from the original profiling study by O'Connell et al. (2009). This KM analysis is particularly useful as it plots the typical path of exits from unemployment in a normal labour market (2007) with light-touch PES assistance and is, therefore, not heavily distorted by PES activities. ${ }^{14}$ The curve may be somewhat flatter during periods of prolonged recession, but the general downward relations would still be expected to hold. The data indicate that, for a given cohort of claimants that enter the Live Register over a set period, ${ }^{15} 25 \%$ will tend to exit to employment between weeks 1 to 20 (approximately). The rate of exit from the Live Register then slows somewhat, with a further $25 \%$ leaving unemployment between weeks 20 and 50 (approximately). The rate of exit slows significantly after week 50 , with a relatively small proportion of claimants, who are now largely classified as long-term unemployed, exiting the Live Register between week 51 and 77.

We can think of the PEX profiling model as a tool that allows PES, on day 1 of a claim, to identify those likely to exit during weeks 1 to 20 as high PEX claimants that need little PES assistance, and those likely to exit over weeks 21 to 50 as medium PEX that will require some level of assistance to obtain appropriate employment and training. Finally, the PEX profiling model would seek to achieve the early identification of claimants whose Live Register durations are likely to exceed 50 weeks for more immediate and intensive activation, designed to substantially reduce these claimants' risk of subsequent long-term unemployment.

Nevertheless, while the application of the current PEX profiling tool appears, at first glance, to be appealing in the current labour market crises brought on by the COVID-19 pandemic, it is arguably no longer appropriate on the following grounds:

1. The current tool has a high administrative burden, as it requires a PES Case Officer to complete almost 20 fields that capture a wide range of information on claimants related to their education attainment, labour market history, health, access to transport, etc. Given the rapid increase in the numbers qualifying for PES, the collection and processing of data at this level of detail is simply not feasible. The workload required of the DEASP's PES Case Officers to go through the volume of claimants required would be too burdensome: it would take a long period of time to complete without substantial increases in

14 McGuinness et al. (2019) remark that during this period job search monitoring and sanctions were virtually nonexistent in Ireland.

15 In this instance, over a 13-week period between September and December 2006. 
the number of Case Officers, which would be costly and would take some time to achieve.

2. The existing PEX model is based on relatively old data from $2007 / 2008$ and is not likely to reflect recent labour market conditions or behaviour: this will tend to have substantially reduced the PEX model's accuracy. Given that the DEASP will have to activate and provide support to a large number of claimants when the PUP ends at the beginning of April 2021, and even before this as a number of claimants will likely seek employment supports in advance of this time point, ${ }^{16}$ there is not enough time for the DEASP to have the PEX model recalibrated and ready for use when it will be needed. Thus, the short-run categorisation tool developed in this paper will assist the Department's PES with this work, and until time permits the Department to have the PEX model recalibrated.

\section{FIGURE 1 CLAIMANT EXITS FROM THE LIVE REGISTER DURING 2007}

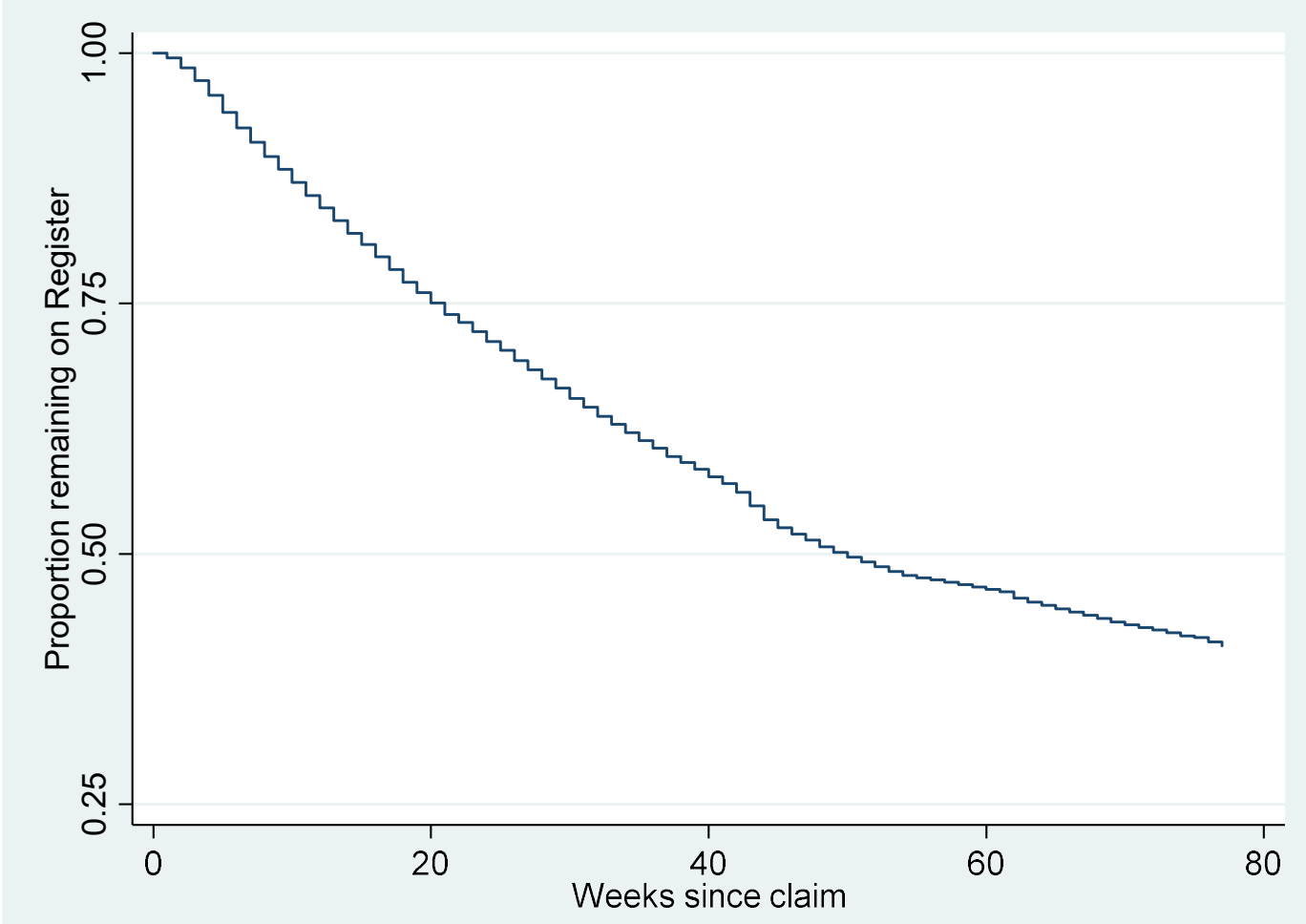

Source:

Constructed using 2007 Live Register claimant data.

16 For example, if a PUP claimant wanted to avail of a Further Education and Training (FET) course, or some other education/training/apprenticeship programme, prior to the termination of the PUP scheme. 


\section{DATA AND METHODS}

In order to develop an effective profile of the PUP claimants, we use a combination of administrative data provided by the DEASP on those receiving a PUP on 12 May 2020 with data from the CSO's Labour Force Survey (LFS) from Q1 2020. ${ }^{17}$ Specifically, the DEASP supplied us with 3-digit NACE sector data for those in receipt of a PUP on 12 May 2020, and we also obtained age and geographic location (county) information. ${ }^{18}$ We accessed employment-level data by economic sector (NACE 2-digit), age and geographic location (NUTS-3) from the CSO's published LFS tables. ${ }^{19}$ Since early June, in addition to the CSO providing gender, age, nationality and geographic location information on PUP claimants, it has started publishing a sectoral breakdown of PUP claimants at the 1-digit NACE level. For the work undertaken in this paper, we needed more refined sectoral information. Therefore, we used the administrative PUP sectoral data provided to us by the DEASP.

We estimate rates of COVID-19 job loss by sector (2-digit NACE), age and geographic location (NUTS-3). ${ }^{20}$ In order to work with the CSO's 2-digit NACE sector and NUTS-3 geographic location data, the PUP sector data were aggregated to 2digit NACE codes and the county-level information to NUTS-3. Due to differences in the coding of NACE in the LFS and PUP data, ${ }^{21}$ some differences emerged. For example, the number of 'employment activities' sector PUP claimants on 12 May 2020 is larger $(19,956)$ than the number employed in this sector in Q1 2020 $(10,200)$. In addition, there are 4839 PUP claimants in the economic sector 'Undifferentiated goods- and services-producing activities of private households for own use', whereas, based on the LFS data, no individuals were employed in this sector in Q1 2020. Aside from these economic sector anomalies, which are excluded from the analysis that follows in the next section, the remaining derived COVID-19 economic sector job loss rates seem plausible, ${ }^{22}$ and the approach provides us with a valuable broad-brush indicator of the employment loss impacts arising from the pandemic.

Most recently available LFS data at time of writing.

Age and geographic location data obtained from Gov.ie website: https://www.gov.ie/en/publication/f4c60c-covid19-statistics/ (accessed 14 March 2020).

19 https://www.cso.ie/en/releasesandpublications/er/lfs/labourforcesurveylfsquarter12020/ (Tables 7 and 9: accessed 21 July 2020); and https://www.cso.ie/en/statistics/labourmarket/labourforcesurveylfstimeseries/ (accessed 22 July 2020).

20 The job loss rates were calculated by dividing the numbers employed within the 2-digit NACE sectors by the numbers in receipt of the PUP for each sector. For example, for 'Accommodation' this was 54,000 individuals employed in this sector in Q1 2020 divided by the 40,590 accommodation sector PUP claimants on 12 May 2020 to give a job loss rate for the sector of $75.2 \%$.

21 Also possibly different timelines for assignment of NACE by the DEASP and the CSO to their respective data.

22 Appendix Table A1 lists a number of economic sectors for which we were not able to derive job loss rates. This is because the CSO did not produce estimates of the numbers employed in these sectors as the estimates would not have been reliable because of small sample sizes (fewer than 30 individuals) associated with these sectors. 
On the basis of the job loss rates analysis, we make recommendations in the final section of the report as to how the DEASP can combine aggregate COVID-19 job loss indicators with limited data collected by the Department on PUP claimant characteristics to develop a short-run categorisation tool to assist it in providing activation services to the large number of PUP claimants that are likely to transfer to a regular jobseeker payment over the next few months. 


\section{COVID-19 PANDEMIC JOB LOSS RATE ANALYSIS}

In Table 2, we set out our derived COVID-19 economic sector job loss rates: the numbers employed in each sector, along with the number of PUP claimants per sector and the sectors' employment shares, are also outlined. We classify the economic sectors into three risk categories on the basis of re-employment probabilities, which, in turn, are based on the sector's job loss rate. Specifically, we have high-risk, medium-risk and low-risk, with high-risk sectors having a job loss rate of $60 \%$ and above, medium-risk $20-59 \%$ and low-risk less than $20 \%$.

The six main economic sectors with high job loss rates are:

(i) other personal service activities, such as hairdressers and beauticians $(76.5 \%)$;

(ii) accommodation (75.2\%);

(iii) real estate activities $(74.8 \%)$;

(iv) food and beverage service activities (73\%);

(v) specialised construction activities, such as demolition and site preparation, electrical, plumbing and other construction installation activities (68\%);

(vi) Motion picture, video and television programme production, sound recording and music publishing activities (67.9\%).

Of these sectors, food and beverages, specialised construction activities and accommodation have high employment shares $-5 \%, 3.2 \%$ and $2.3 \%$ respectively; whereas even though real estate activities has the second highest job loss rate, its share of total employment in the economy is only $0.5 \%$.

In addition, we classify two travel industry sectors as high risk: (i) travel agency, tour operator and other reservation service and related activities, and (ii) air transport. Based on their employment loss shares, these sectors would be classified as medium (23.4\%) and low risk (6.9\%). However, given that this industry is going to be one of the last to resume operations, and will likely experience more medium-term impacts, these two sectors have been reclassified as high-risk.

In total, high-risk sectors accounted for $13.6 \%$ of total employment prior to the pandemic and make up $37.5 \%$ of PUP claimants that could be classified according to economic sector. It is worth noting that this proportion aligns with the finding of O'Connell et al. (2013) that $39 \%$ of new claimants in their sample subsequently fell into long-term unemployment. 
On the basis of job loss rates, the three main medium-risk sectors are:

(i) activities of head offices, management consultancy activities (53.3\%);

(ii) manufacture of other non-metallic mineral products (50.6\%);

(iii) Construction of buildings (41.3\%).

Of these three sectors, construction of buildings has the largest employment share: $2.3 \%$ compared to less than $1 \%$ for the other two sectors combined $0.5 \%$ for activities of head offices, management consultancy activities; and $0.3 \%$ for manufacture of other non-metallic mineral products).

Some of the medium-risk sectors with large shares of employment but lower job loss rates are:

(i) retail trade, except for motor vehicles and motorcycles (employment share $9.1 \%$, and job loss rate $27 \%$ );

(ii) wholesale trade, except of motor vehicles and motorcycles (employment share $2.7 \%$ and job loss rate $28.5 \%$ );

(iii) land transport and transport via pipelines (employment share $2.2 \%$ and job loss rate $21.6 \%$ );

(iv) services to buildings and landscape activities (employment share $1.9 \%$ and job loss rate $26.1 \%)$. 


\begin{tabular}{|c|c|c|c|c|c|}
\hline $\begin{array}{l}\text { 2-Digit } \\
\text { NACE code }\end{array}$ & NACE economic sector & Employment number & $\begin{array}{l}\text { PUP } \\
\text { claimants }\end{array}$ & $\begin{array}{l}\text { Job } \\
\text { loss } \\
\text { rate } \\
(\%)\end{array}$ & $\begin{array}{l}\text { Employment share } \\
\text { (\%) }\end{array}$ \\
\hline \multicolumn{6}{|c|}{ High-risk economic sectors (job loss rate $60 \%$ and above): } \\
\hline 96 & Other personal service activities (e.g. hairdressing, beauty treatment) & 37,300 & 28,544 & 76.5 & 1.6 \\
\hline 55 & Accommodation & 54,000 & 40,590 & 75.2 & 2.3 \\
\hline 68 & Real estate activities & 10,800 & 8081 & 74.8 & 0.5 \\
\hline 56 & Food and beverage service activities & 116,600 & 85,149 & 73.0 & 5.0 \\
\hline 43 & $\begin{array}{l}\text { Specialised construction activities (demolition and site preparation, } \\
\text { electrical, plumbing and other construction installation activities, etc.) }\end{array}$ & 74,900 & 50,955 & 68.0 & 3.2 \\
\hline 59 & $\begin{array}{l}\text { Motion picture, video and television programme production, sound } \\
\text { recording and music publishing activities }\end{array}$ & 7700 & 5232 & 67.9 & 0.3 \\
\hline \multicolumn{6}{|l|}{$\begin{array}{l}\text { Special } \\
\text { cases: }\end{array}$} \\
\hline 79 & $\begin{array}{l}\text { Travel agency, tour operator and other reservation service and related } \\
\text { activities }\end{array}$ & 8700 & 2033 & 23.4 & 0.4 \\
\hline 51 & Air transport & 8500 & 586 & 6.9 & 0.4 \\
\hline Total & & 318,500 & 221,170 & - & 13.6 \\
\hline \multicolumn{6}{|c|}{ Medium-risk economic sectors (job loss rate $20-59 \%$ ): } \\
\hline 70 & Activities of head offices; management consultancy activities & 10,900 & 5809 & 53.3 & 0.5 \\
\hline 23 & Manufacture of other non-metallic mineral products & 7500 & 3793 & 50.6 & 0.3 \\
\hline 41 & Construction of buildings & 55,100 & 22,780 & 41.3 & 2.3 \\
\hline 31 & Manufacture of furniture & 6700 & 2612 & 39.0 & 0.3 \\
\hline 45 & Wholesale and retail trade and repair of motor vehicles and motorcycles & 33,400 & 12,733 & 38.1 & 1.4 \\
\hline 93 & Sports activities and amusement and recreation activities & 26,800 & 10,150 & 37.9 & 1.1 \\
\hline 65 & $\begin{array}{l}\text { Insurance, reinsurance and pension funding, except compulsory social } \\
\text { security }\end{array}$ & 23,800 & 7327 & 30.8 & 1.0 \\
\hline 77 & Rental and leasing activities & 12,900 & 3819 & 29.6 & 0.5 \\
\hline 46 & Wholesale trade, except of motor vehicles and motorcycles & 63,100 & 18,004 & 28.5 & 2.7 \\
\hline 25 & $\begin{array}{l}\text { Manufacture of fabricated metal products, except machinery and } \\
\text { equipment }\end{array}$ & 15,200 & 4270 & 28.1 & 0.6 \\
\hline
\end{tabular}




\begin{tabular}{|c|c|c|c|c|c|}
\hline $\begin{array}{c}\text { 2-Digit } \\
\text { NACE code }\end{array}$ & NACE economic sector & Employment number & $\begin{array}{c}\text { PUP } \\
\text { claimants }\end{array}$ & $\begin{array}{l}\text { Job } \\
\text { loss } \\
\text { rate } \\
(\%)\end{array}$ & $\begin{array}{c}\text { Employment share } \\
(\%)\end{array}$ \\
\hline 82 & Office administrative, office support and other business support activities & 15,400 & 4246 & 27.6 & 0.7 \\
\hline 47 & Retail trade, except of motor vehicles and motorcycles & 213,300 & 57,688 & 27.0 & 9.1 \\
\hline 58 & Publishing activities & 5100 & 1355 & 26.6 & 0.2 \\
\hline 81 & Services to buildings and landscape activities & 44,000 & 11,485 & 26.1 & 1.9 \\
\hline 42 & Civil engineering & 17,700 & 4321 & 24.4 & 0.8 \\
\hline 24 & Manufacture of basic metals & 6300 & 1388 & 22.0 & 0.3 \\
\hline 22 & Manufacture of rubber and plastic products & 6600 & 1426 & 21.6 & 0.3 \\
\hline 49 & Land transport and transport via pipelines & 51,900 & 11,209 & 21.6 & 2.2 \\
\hline 92 & Gambling and betting activities & 8000 & 1682 & 21.0 & 0.3 \\
\hline 94 & Activities of membership organisations & 20,100 & 4216 & 21.0 & 0.9 \\
\hline 80 & Security and investigation activities & 20,500 & 4158 & 20.3 & 0.9 \\
\hline 28 & Manufacture of machinery and equipment n.e.c. & 10,500 & 2125 & 20.2 & 0.4 \\
\hline Total & & 674,800 & 196,596 & - & 28.7 \\
\hline \multicolumn{6}{|c|}{ Low-risk economic sectors (job loss rate $<20 \%$ ): } \\
\hline 33 & Repair and installation of machinery and equipment & 6900 & 1337 & 19.4 & 0.3 \\
\hline 38 & Waste collection, treatment and disposal activities; materials recovery & 6900 & 1217 & 17.6 & 0.3 \\
\hline 18 & Printing and reproduction of recorded media & 9300 & 1621 & 17.4 & 0.4 \\
\hline 74 & Other professional, scientific and technical activities & 19,600 & 3251 & 16.6 & 0.8 \\
\hline 53 & Postal and courier activities & 13,800 & 2209 & 16.0 & 0.6 \\
\hline 73 & Advertising and market research & 15,300 & 2295 & 15.0 & 0.7 \\
\hline 91 & Libraries, archives, museums and other cultural activities & 5600 & 805 & 14.4 & 0.2 \\
\hline 10 & Manufacture of food products & 44,600 & 6250 & 14.0 & 1.9 \\
\hline 08 & Other mining and quarrying & 5600 & 777 & 13.9 & 0.2 \\
\hline 90 & Creative, arts and entertainment activities & 11,400 & 1568 & 13.8 & 0.5 \\
\hline 71 & Architectural and engineering activities; technical testing and analysis & 39,700 & 5327 & 13.4 & 1.7 \\
\hline 69 & Legal and accounting activities & 53,200 & 7102 & 13.3 & 2.3 \\
\hline 11 & Manufacture of beverages & 6300 & 788 & 12.5 & 0.3 \\
\hline 84 & Public administration and defence; compulsory social security & 115,600 & 14,317 & 12.4 & 4.9 \\
\hline 85 & Education & 192,500 & 21,855 & 11.4 & 8.2 \\
\hline
\end{tabular}




\begin{tabular}{|c|c|c|c|c|c|}
\hline $\begin{array}{l}\text { 2-Digit } \\
\text { NACE code }\end{array}$ & NACE economic sector & Employment number & $\begin{array}{l}\text { PUP } \\
\text { claimants }\end{array}$ & $\begin{array}{l}\text { Job } \\
\text { loss } \\
\text { rate } \\
(\%)\end{array}$ & $\begin{array}{l}\text { Employment share } \\
(\%)\end{array}$ \\
\hline 52 & Warehousing and support activities for transportation & 28,300 & 3161 & 11.2 & 1.2 \\
\hline 66 & Activities auxiliary to financial services and insurance activities & 14500 & 1611 & 111 & 0.6 \\
\hline 88 & Social work activities without accommodation & 88,100 & 9192 & 10.4 & 3.7 \\
\hline 29 & Manufacture of motor vehicles, trailers and semi-trailers & 4800 & 468 & 9.8 & 0.2 \\
\hline 87 & Residential care activities & 44,500 & 3261 & 7.3 & 1.9 \\
\hline 01 & Crop and animal production, hunting and related service activities & 101,200 & 6723 & 6.6 & 4.3 \\
\hline 86 & Human health activities & 157,400 & 9344 & 5.9 & 6.7 \\
\hline 72 & Scientific research and development & 6900 & 398 & 5.8 & 0.3 \\
\hline 97 & Activities of households as employers of domestic personnel & 5300 & 300 & 5.7 & 0.2 \\
\hline 64 & Financial service activities, except insurance and pension funding & 70,600 & 3607 & 5.1 & 3.0 \\
\hline 62 & Computer programming, consultancy and related activities & 83,900 & 4049 & 4.8 & 3.6 \\
\hline 26 & Manufacture of computer, electronic and optical products & 21,900 & 870 & 4.0 & 0.9 \\
\hline 32 & Other manufacturing & 44,800 & 1643 & 3.7 & 1.9 \\
\hline 35 & Electricity, gas, steam and air conditioning supply & 10,900 & 361 & 3.3 & 0.5 \\
\hline 63 & Information service activities & 8600 & 273 & 3.2 & 0.4 \\
\hline 61 & Telecommunications & 19,100 & 567 & 3.0 & 0.8 \\
\hline 21 & $\begin{array}{l}\text { Manufacture of basic pharmaceutical products and pharmaceutical } \\
\text { preparations }\end{array}$ & 46,900 & 528 & 1.1 & 2.0 \\
\hline Total & & $1,304,000$ & 117,075 & - & 55.4 \\
\hline
\end{tabular}

Source: Constructed using 12 May 2020 PUP Claimant Economic Sector data (DEASP) and Q1 2020 LFS data (CSO).

Note: n.e.c.: not elsewhere classified. 
In total, medium-risk sectors accounted for $28.7 \%$ of employment prior to the pandemic and $33.3 \%$ of PUP claimants that could be classified according to sector.

The main low-risk sectors on the basis of their job loss rates are:

(i) repair and installation of machinery and equipment (19.4\%);

(ii) waste collection, treatment and disposal activities; materials recovery (17.6\%);

(iii) printing and reproduction of recorded media (17.4\%);

(iv) other professional, scientific and technical activities (16.6\%);

(v) postal and courier activities (16\%).

Each of these low-risk sectors has a low share of total employment: $2.4 \%$. On the other hand, the low-risk sectors with high employment shares include:

(i) education (employment share $8.2 \%$ and job loss rate $11.4 \%$ );

(ii) human health activities (employment share 6.7\% and job loss rate 5.9\%);

(iii) public administration and defence; compulsory social security (employment share $4.9 \%$ and job loss rate $12.4 \%)$;

(iv) crop and animal production, hunting and related service activities (employment share $4.3 \%$ and job loss rate $6.6 \%$ );

(v) social work activities without accommodation (employment share $3.7 \%$ and job loss rate $10.4 \%)$.

In total, low-risk sectors accounted for $55.4 \%$ of employment prior to the pandemic and $19.9 \%$ of PUP claimants that could be classified according to sector. Many of the claimants in these sectors are in public sector jobs (e.g. teachers) and, while they may not return to employment in the short term, they should be able to do so once there is more stability around the virus's transmission rate. With regard to human health activities, a certain proportion of these individuals may be able to resume employment once a workable childcare plan is put in place for frontline staff that are unable to work at present because of childcare needs.

Table 3 presents our COVID-19 age category job loss rates, along with, again, the numbers employed in each age category, the number of PUP claimants by age category and employment shares by age group. Interestingly, those aged under 25 have the highest job loss rate (46.7\%) but the lowest share of total employment in the economy (11\%). The age category with the highest employment share is those aged $35-44$, and its job loss rate is $22.6 \%$. Those aged 55 and above have the lowest 
job loss rate (18.6\%) and also a low share of employment (18.4\%).

TABLE 3

COVID-19 JOB LOSS RATES: AGE CATEGORY

\begin{tabular}{|l|c|c|c|c|}
\hline Age category & $\begin{array}{c}\text { Employment } \\
\text { number }\end{array}$ & $\begin{array}{c}\text { PUP } \\
\text { claimants }\end{array}$ & $\begin{array}{c}\text { Job loss } \\
\text { rate (\%) }\end{array}$ & $\begin{array}{c}\text { Employment } \\
\text { share (\%) }\end{array}$ \\
\hline Under $\mathbf{2 5}$ & 258,600 & 120,800 & 46.7 & 11.0 \\
\hline $\mathbf{2 5 - 3 4}$ & 500,100 & 135,100 & 27.0 & 21.3 \\
\hline $\mathbf{3 5 - 4 4}$ & 624,700 & 141,400 & 22.6 & 26.5 \\
\hline $\mathbf{4 5 - 5 4}$ & 536,900 & 111,700 & 20.8 & 22.8 \\
\hline $\mathbf{5 5 +}$ & 433,100 & 80,600 & 18.6 & 18.4 \\
\hline Total & $2,353,400$ & 589,600 & & 100 \\
\hline
\end{tabular}

Source: Constructed using 12 May 2020 PUP Claimant Economic Sector data (DEASP) and Q1 2020 LFS data (CSO).

Finally, with respect to geographic location (Table 4), the border region, which relates to counties Cavan, Donegal, Leitrim, Monaghan and Sligo, has the highest job loss rate $(29.1 \%)$, but a low share of total employment $(7.5 \%)$. On the other hand, Dublin has the lowest job loss rate (23.9\%) and the highest share of employment in the economy (30.5\%).

\begin{tabular}{|l|c|c|c|c|}
\hline \multicolumn{1}{|c|}{ NUTS-3 region } & $\begin{array}{c}\text { Employment } \\
\text { number }\end{array}$ & $\begin{array}{c}\text { PUP } \\
\text { claimants }\end{array}$ & $\begin{array}{c}\text { Job loss } \\
\text { rate (\%) }\end{array}$ & $\begin{array}{c}\text { Employment } \\
\text { share (\%) }\end{array}$ \\
\hline Border & 177,400 & 51,600 & 29.1 & 7.5 \\
\hline South-East & 195,900 & 52,300 & 26.7 & 8.3 \\
\hline Mid-West & 218,400 & 54,800 & 25.1 & 9.3 \\
\hline West & 223,500 & 55,200 & 24.7 & 9.5 \\
\hline Mid-East & 340,500 & 85,900 & 25.2 & 14.5 \\
\hline Midlands & 135,300 & 33,300 & 24.6 & 14.6 \\
\hline South-West & 344,400 & 82,900 & 24.1 & 30.5 \\
\hline Dublin & 718,000 & 171,900 & 23.9 & \\
\hline No County Information & - & 1700 & - & 100 \\
\hline Total & $2,353,400$ & 589,600 & & \\
\hline
\end{tabular}

Source: Constructed using 12 May 2020 PUP Claimant Economic Sector data (DEASP) and Q1 2020 LFS data (CSO). 


\section{APPROACH TO PROFILING NEW ENTRANTS TO THE LIVE REGISTER}

The primary means of sorting individuals according to their risk of becoming longterm unemployed will relate to whether they were previously employed in a highrisk sector, which we defined in Section 5 as sectors with a job loss rate of $60 \%$ or above. Re-employment probabilities in high-risk sectors are likely to be substantially restricted due to high levels of employment loss (i.e. excessive labour supply), structural factors related to continued social distancing, and deep-cleaning requirements and strict hand-sanitising in place, or both.

In addition to sector, a number of individual factors will impact re-employment probabilities and, therefore, can be used to further repartition the new PUP entrants to the Live Register. In particular, age, previous unemployment history and geographic location are known to be important determinants of an individual's risk of becoming long-term unemployed (see O'Connell et al., 2009).

With respect to age, although persons aged 25 and under have been disproportionately adversely impacted with respect to employment loss because of this pandemic (Section 3), it is typically older unemployed claimants that struggle to find re-employment. O'Connell et al. (2013) found that male (female) claimants aged 55 or over were almost 22 (10) percentage points more likely to fall into long-term unemployment that those aged 24 or under.

With regard to labour market history, males (females) with a previous history of long-term unemployment are almost 17 (19) percentage points more likely to fall into long-term unemployment compared to those with no previous history of longterm unemployment (O'Connell et al., 2013).

Finally, O'Connell et. al (2013) found significant variations in the probability of longterm unemployment by county. Specifically, the risk was found to be much higher in rural counties. Interestingly, some of the highest percentage point impacts of falling into long-term unemployment were in Border counties that have also been disproportionately impacted by the COVID-19 pandemic (e.g. Cavan $17.5 \% / 16.5 \%$, Sligo $10 \% / 11 \%$ for males/females). Geographical impacts were also important for male (female) claimants in Longford when compared to Dublin: 18 (16) percentage points.

Therefore, there are sufficient data to allow for the initial sorting of new claimants that will transfer from the PUP to a regular jobseeker payment over the next couple of months, in terms of their risk of becoming long-term unemployed in the future, by using economic sector (two-digit NACE) and then a further separation within 
this principal risk measure according to age, previous unemployment history and geographic location.

The interim long-term unemployment risk categorisation strategy that the use of these data gives rise to is set out as a PUP Matrix in Table 5; an illustration of how the matrix might operate in practice is presented in Table 6 .

As can be seen from Table 5, using the limited data available to the DEASP on PUP claimants, current recipients of the payment that will have to be transferred to a regular jobseeker payment in the next few months can have their risk of becoming long-term unemployed scored on a scale of 1-9, with claimants that score a 9 being at the greatest risk of becoming long-term unemployed in the future, while those that score 1 are at least risk.

Claimants that score a 9 are those that are in a high-risk sector and possess two or more of the other three characteristics that we know are important determinants of long-term unemployment risk: aged 55 or above, having a history of long-term unemployment and living in a rural area. In the context of this current health pandemic, and based on job loss rates by region (Table 4), rural areas are, for the most part, the counties located in the Border and South-East regions. An example of a present PUP claimant that might score a 9 is a hotel waitress/waiter who possesses two or more of the following characteristics: aged 55 or above, has been previously long-term unemployed, lives in a Border county (e.g. Monaghan).

Claimants that score an 8 or a 7 are also in a high-risk sector. However, those that score an 8 will possess only one of the three aforementioned long-term unemployment risk characteristics; a person will be scored a 7 if he/she possesses none of those long-term unemployment risk traits but is in a high-risk sector.

Claimants in a medium-risk sector will be scored between 4 and 6 , with the specific score depending on the number of long-term unemployment risk characteristics that the PUP recipient possesses. The same is true for claimants in a low-risk sector: they will be scored between 1 and 3, depending on the number of long-term unemployment risk traits that they possess.

An example of a medium-risk sector PUP claimant that scores a 5 is a former wholesale worker (in food, beverages and tobacco) who possesses one of three characteristics associated with long-term unemployment risk. A healthcare claimant is an example of a low-risk sector individual that would be scored a 1. It should be noted that the proposed framework is flexible as the PES can adjust the sectoral employment thresholds, or add additional individual characteristics to the 
criteria, in order to repartition the flows to meet objectives or resource requirements.

\section{TABLE 5 PUP MATRIX}

\section{High-risk sector}

Score 9:

Two or more characteristics (geographic location, i.e. rural area, previously long-term unemployed, age 55+)
Score 6:

Two or more characteristics (geographic location, i.e., rural area, previously long-term unemployed, age 55+)

\section{Low-risk sector}

Score 3:

Two or more characteristics (geographic location, i.e. rural area, previously long-term unemployed, age $55+$ )

\section{Score 8:}

One characteristic

(geographic location, i.e. rural area or previously long-term unemployed or age $55+$ )

\section{Score 5:}

One characteristic (geographic location i.e., rural area or previously long-term unemployed or age $55+$ )

\section{Score 2:}

One characteristic

(geographic location i.e., rural area or previously long-term unemployed or age 55+)
Score 7:

Zero characteristics
Score 4:

Zero characteristics
Score 1:

Zero characteristics

Note: $\quad$ See Table 2 for sector classification (high-, medium- and low-risk sectors). 


\begin{tabular}{|c|c|c|}
\hline High-risk sector & Medium-risk sector & Low-risk sector \\
\hline $\begin{array}{l}\text { Score 9: } \\
\text { Hotel waiter/waitress (NACE } \\
\text { code 55) and has two of the } \\
\text { following characteristics: } \\
\text { - aged } 55 \text { or above; } \\
\text { - previous history of long-term } \\
\text { - unemployment; } \\
\text { lives in Border region (e.g. } \\
\text { Monaghan). }\end{array}$ & $\begin{array}{l}\text { Score 6: } \\
\text { Music producer (NACE code 59) } \\
\text { and has two of the following } \\
\text { characteristics: } \\
\text { - } \quad \text { aged } 55 \text { or above; } \\
\text { - previous history of long-term } \\
\text { - unemployment; } \\
\text { lives in South-East region (e.g. } \\
\text { Carlow). }\end{array}$ & $\begin{array}{l}\text { Score 3: } \\
\text { Photographer (NACE code 74) } \\
\text { and has two of the following } \\
\text { characteristics: } \\
\text { - } \quad \text { aged } 55 \text { or above; } \\
\text { - previous history of long- } \\
\text { term unemployment; } \\
\text { - lives in South-East region } \\
\text { (e.g. Wexford). }\end{array}$ \\
\hline $\begin{array}{l}\text { Score 8: } \\
\text { Bar person (NACE code 56) and } \\
\text { has one of the following } \\
\text { characteristics: } \\
\text { - aged } 55 \text { or above; } \\
\text { - previous history of long-term } \\
\text { - unemployment; } \\
\text { lives in Border region. }\end{array}$ & $\begin{array}{l}\text { Score 5: } \\
\text { Wholesaler of food, beverages and } \\
\text { tobacco (NACE code } 46 \text { ) and has } \\
\text { one of the following } \\
\text { characteristics: } \\
\text { - aged } 55 \text { or above; } \\
\text { - previous history of long-term } \\
\text { - unemployment; } \\
\text { lives in South-East region. }\end{array}$ & $\begin{array}{l}\text { Score 2: } \\
\text { Teacher (NACE code } 85 \text { ) and has } \\
\text { one of the following } \\
\text { characteristics: } \\
\text { - aged } 55 \text { or above; } \\
\text { - previous history of long- } \\
\text { - term unemployment; } \\
\text { lives in Border region. }\end{array}$ \\
\hline Score 7: & Score 4: & Score 1: \\
\hline $\begin{array}{l}\text { Hairdresser/barber; beautician } \\
\text { (NACE code } 96 \text { ). }\end{array}$ & $\begin{array}{l}\text { Betting shop employee (NACE code } \\
\text { 92). }\end{array}$ & $\begin{array}{l}\text { Healthcare worker (NACE code } \\
\text { 86). }\end{array}$ \\
\hline
\end{tabular}

Note: $\quad$ See Table 2 for sector classification (high-, medium-and low-risk sectors). 


\section{SUMMARY AND CONCLUSIONS}

The Irish labour market is experiencing an unprecedented crisis that has seen the unemployment rate increase from $4.8 \%$ in February 2020 to an estimated $28.2 \%$ in April 2020 when those in receipt of the Pandemic Unemployment Payment (PUP) are included. Currently (June), the rate is $22.5 \%$. Given the current uncertainty around the behaviour of the virus, and in the absence of a vaccination, Ireland's Public Employment Services (PES) are likely to be overwhelmed as a result of the rapid increase in individuals qualifying for, and/or seeking, employment supports. Furthermore, PES will be responsible for transferring a large number of COVID-19 Pandemic Unemployment Payment (PUP) claimants to a standard jobseeker payment when the PUP is terminated at the end of March 2021. Even with further substantial falls in the number of claimants in receipt of the PUP, the number of individuals that will ultimately transfer to the Live Register is likely to be unprecedented.

In this paper we combine administrative PUP data with data from the Irish Labour Force Survey (LFS) to develop an interim profiling approach that will allow the Department of Employment Affairs and Social Protection's PES to potentially manage new inflows according to future long-term unemployment risk.

We propose that the primary means of sorting individuals according to their risk of becoming long-term unemployed in the future should relate to whether they were previously employed in a high-risk economic sector, which we define as sectors with a job loss rate because of the current pandemic of $60 \%$ or above. High-risk sectors accounted for $13.6 \%$ of total employment prior to the pandemic and make up $37.5 \%$ of PUP claimants. Factors such as age, previous unemployment history and geographic location can also be used to repartition claimants according to future long-term unemployment risk.

We set out a potential approach that will allow the DEASP to categorise present PUP claimants that transfer to a regular jobseeker payment in terms of risk of subsequent long-term unemployment on a scale of 1 to 9 , with the score that the claimant receives depending on the limited data that will be available to the Department when this transfer takes place. The proposed framework is flexible as the PES can adjust the sectoral employment thresholds, or add additional individual characteristics to the criteria, in order to repartition the flows to meet available objectives and resource requirements. 


\section{REFERENCES}

Kelly, E., S. McGuinness, P. Redmond, M. Savage, and J.R. Walsh (2019). An initial evaluation of the effectiveness of Intreo activation reforms, Research Series No. 81, Dublin: The Economic and Social Research Institute.

McGuinness, S., P.J. O'Connell, and E. Kelly (2019). 'Carrots, no stick, no driver: the employment impact of job search assistance in a regime with minimal monitoring and sanctions', Journal of Labor Research, Vol. 40, No. 2, 151-180.

O'Connell, P.J., S. McGuinness, and E. Kelly (2013). 'The transition from short- to long-term unemployment: a statistical profiling model for Ireland', The Economic and Social Review, Vol. 43, No. 1, pp. 135-164.

O'Connell, P.J., S. McGuinness, E. Kelly, and J.R. Walsh (2009). National profiling of the unemployed in Ireland, Research Series No. 10, Dublin: The Economic and Social Research Institute. 


\section{APPENDIX}

TABLE A1 COVID-19 JOB LOSS RATES: ECONOMIC SECTOR

\begin{tabular}{|c|c|c|c|c|}
\hline $\begin{array}{l}\text { 2-Digit } \\
\text { NACE code }\end{array}$ & NACE economic sector & $\begin{array}{l}\text { Employment } \\
\text { number }\end{array}$ & PUP claimants & $\begin{array}{l}\text { Job loss } \\
\text { rates }\end{array}$ \\
\hline 02 & Forestry and logging & $*$ & 483 & $*$ \\
\hline 03 & Fishing and aquaculture & $*$ & 596 & $*$ \\
\hline 05 & Mining of coal and lignite & $*$ & 2 & $*$ \\
\hline 06 & Extraction of crude petroleum and natural gas & $*$ & 1 & $*$ \\
\hline 07 & Mining of metal ores & $*$ & 31 & $*$ \\
\hline 09 & Mining support service activities & $*$ & 20 & $*$ \\
\hline 12 & Manufacture of tobacco products & $*$ & 22 & * \\
\hline 13 & Manufacture of textiles & $*$ & 901 & $*$ \\
\hline 14 & Manufacture of wearing apparel & $*$ & 905 & $*$ \\
\hline 15 & Manufacture of leather and related products & $*$ & 156 & $*$ \\
\hline 16 & $\begin{array}{l}\text { Manufacture of wood and of products of wood } \\
\text { and cork, except furniture; manufacture of } \\
\text { articles of straw and plaiting materials }\end{array}$ & * & 1994 & $*$ \\
\hline 17 & Manufacture of paper and paper products & $*$ & 874 & $*$ \\
\hline 19 & $\begin{array}{l}\text { Manufacture of coke and refined petroleum } \\
\text { products }\end{array}$ & $*$ & 28 & $*$ \\
\hline 20 & $\begin{array}{l}\text { Manufacture of chemicals and chemical } \\
\text { products }\end{array}$ & $*$ & 596 & $*$ \\
\hline 27 & Manufacture of electrical equipment & $*$ & 867 & $*$ \\
\hline 30 & Manufacture of other transport equipment & $*$ & 436 & $*$ \\
\hline 36 & Water collection, treatment and supply & $*$ & 103 & $*$ \\
\hline 37 & Sewerage & $*$ & 284 & $*$ \\
\hline 39 & $\begin{array}{l}\text { Remediation activities and other waste } \\
\text { management services }\end{array}$ & $*$ & 50 & $*$ \\
\hline 50 & Water transport & $*$ & 128 & $*$ \\
\hline 60 & Programming and broadcasting activities & $*$ & 339 & $*$ \\
\hline 75 & Veterinary activities & $*$ & 495 & $*$ \\
\hline 95 & $\begin{array}{l}\text { Repair of computers and personal and } \\
\text { household goods }\end{array}$ & $*$ & 1307 & $*$ \\
\hline 99 & $\begin{array}{l}\text { Activities of extraterritorial organisations and } \\
\text { bodies }\end{array}$ & $*$ & 12 & $*$ \\
\hline & Unknown & $*$ & 19,372 & $*$ \\
\hline Total & & & 30,002 & \\
\hline
\end{tabular}

Source: $\quad$ Constructed using 12 May 2020 PUP Claimant Economic Sector data (DEASP) and Q1 2020 LFS data (CSO).

Note: $\quad *$ Where there are fewer than 30 persons in a cell, the CSO does not produce estimates for numbers of persons in the economic sector as the estimates produced would be too small to be considered reliable. Hence, we were unable to derive job loss rates for these sectors, which constituted 2.3\% of employment in Q1 2020. 
Whitaker Square,

Sir John Rogerson's Quay, Dublin 2

Telephone +35318632000

Email admin@esri.ie

Web www.esri.ie

Twitter @ESRIDublin

ISBN 978-0-7070-0533-1 